\title{
REFRIGERATED STORAGE PERIOD OF RHIZOPHORES FOR YACON PROPAGATION
}

\author{
PERÍODOS DE ARMAZENAMENTO REFRIGERADO DE RIZÓFOROS PARA \\ PROPAGAÇÃO DE YACON
}

\author{
Mateus Augusto Lima QUARESMA ${ }^{1}$; Fabio Luiz de OLIVEIRA ${ }^{\mathbf{1}}$; \\ Magno do Carmo PARAJARA ${ }^{1}$; Diego Mathias Natal da SILVA ${ }^{2}$; \\ Leandro Pin DALVI ${ }^{1}$; Ariany das Graças TEIXEIRA ${ }^{1}$ \\ 1. Departamento de Agronomia, Centro de Ciências Agrárias e Engenharias, Universidade Federal do Espírito Santo, Alegre, ES, Brasil. \\ arianyteixeira@yahoo.com.br; 2. Instituto Federal do Sudeste de Minas Gerais, Manhuaçu, MG, Brasil.
}

\begin{abstract}
The yacon plant produces tuberous roots, used mostly for fresh consumption. This crop is propagated primarily via vegetative structures, called rhizophores. However, since these propagules have short periods of viability after harvest, storing them in cold chamber conditions may be a viable alternative to optimize yacon seedling production. The objective of this study was to test the effect of the refrigerated storage period of yacon rhizophores on seedling development. The experimental design was completely randomized, with eight replications, containing 30 useful plants per replication. Treatments were cold storage periods of propagative materials $(35,28,21,14$, and 7 days) and a control (planting without storage). The results show that keeping rhizophores in cold storage under temperatures of $8{ }^{\circ} \mathrm{C}\left( \pm 2^{\circ} \mathrm{C}\right)$ for a period between 21 to 35 days improves sprouting rates (speed and vigorousness), reducing seedling mortality and favoring initial yacon growth. The refrigerated storage for 21 and 35 days proved to be an alternative to achieve improved plant stand in production fields, reflecting in more uniform harvest, and minimizing the problem of seasonal availability of propagative material.
\end{abstract}

KEYWORDS: Cold chamber. Growth. Propagule conservation. Smallanthus sonchifolius.

\section{INTRODUCTION}

The yacon (Smallanthus sonchifolius) plant produces tuberous roots, used mostly for fresh consumption, but many sub-products were developed to take advantage of yacon's nutraceutical potential. These products include sweeteners, juices, teas (leaves), and flour (leaves and/or roots). An increase in the yacon demand by the food industry to produce nutraceutical and/or functional foods led to an expansion in the production areas (SANTANA; CARDOSO 2008; GUSSO et al. 2015).

The harvest of yacon tuberous roots occurs six months after planting, depending on the growing region, usually when shoots start to dry out (GRAU; REA 1997). During harvest, the rhizophores, which are used as propagative material, are also collected to be used in the next cropping season. Similar to most yacon ecotypes introduced in countries outside the region of origin (Andes), they do not produce viable seeds (VITALI et al. 2015).

The propagation of yacon via rhizophores collected at harvest challenges production systems. There is a seasonal provision of propagules at harvest, which occurs at a period of high temperatures, not favorable for yacon planting (SILVA et al. 2018). Consequently, rhizophores need to be store between two to four months and later planted in a favorable season. Under these circumstances, rhizophore storage and fractioning may be alternatives to minimize the seasonality and maximize the growth of new plants.

The storage methods of propagative materials (vegetative) can maintain, increase or decrease the viability of the rhizophores, directly influencing crop development and productivity, as observed for Peruvian carrot (ZARATE et al. 2011) and garlic (KIMOTO et al. 1996). The requirements for storage of propagules (temperature, humidity, and light) to maintain viability will depend on the morphophysiological characteristics of each species. Although the literature provides studies on storage and conservation of Andean species such as potato (Solanum tuberosum) (BOOCK; NÓBREGA, 1963; FONTES; FINGER, 1999), Peruvian carrot (ZARATE et al.., 2011), little is known about the ideal period and storage conditions of yacon rhizophores, and its possible effects on the seedling development.

Therefore, the objective of this study was to test the refrigerated storage period of yacon rhizophores and the effect on seedling development. 


\section{MATERIALS AND METHODS}

The experiment was conducted from December to April 2016, in a greenhouse (without temperature and humidity control) with shading (Sombrite ${ }^{\circledR}$ ) at $50 \%$ of light restriction. The greenhouse was located in the Federal University of Espírito Santo (UFES) Research Farms, Alegre/ES, $20^{\circ} 45^{\prime} 02^{\prime \prime} \mathrm{S}, 41^{\circ} 23^{\prime} 14^{\prime \prime}$, with an elevation of $116 \mathrm{~m}$. The thermal amplitude in the experimental period was 19.2 to $29.7^{\circ} \mathrm{C}$ and the relative humidity varied between 50 and 99\% (INMET 2018).

The experimental design was completely randomized, with eight replications, containing 30 useful plants per replication. Treatments were periods of cold storage of the propagation material $(35,28,21,14$, and 7 days) and a control (planting without storage).

The rhizophores were collected from an experimental yacon field, conducted in the UFES Research Farms, Alegre/ES. The rhizophores were collected at the end of the cultivation cycle, which was late autumn (12.15.2015), when the plants achieved $80 \%$ senescence $(10$ months after planting). Rhizophores were selected based in the following characteristics: containing 3 to 5 buds and weighing 7 to $10 \mathrm{~g}$.

The propagules were packed in perforated polyethylene bags to decrease the water loss of the rhizophores and prevent excessive water condensation. Following, rhizophores were stored in a refrigerator with a temperature of 8 to $10^{\circ} \mathrm{C}$, average relative humidity of $80 \%$ (monitored with the aid of a thermo-hygrometer ITHT digital model 2210, Instrument) during the studied periods. Rhizophores were planted individually in conical tubes of $280 \mathrm{~cm}^{3}$, always at the same time, once a week (depending on the studied storage period).

The substrate used was formulated with $50 \%$ of soil and $50 \%$ of organic compost $(\mathrm{v} / \mathrm{v})$. The soil was classified as a Red-Yellow Ultisol (Embrapa 2014), clay texture, collected from the "arable layer" (0 to $20 \mathrm{~cm}$, topsoil). Chemical analysis resulted in the following: $\mathrm{pH}=7.15 ; \mathrm{Al}=$ $2.5 \mathrm{cmol}_{\mathrm{c}} \mathrm{dm}^{-3} ; \mathrm{Ca}=1.9 \mathrm{cmol}_{\mathrm{c}} \mathrm{dm}^{-3} ; \mathrm{Mg}=1.8$ $\mathrm{cmol}_{\mathrm{c}} \mathrm{dm}^{-3} ; \mathrm{P}=11.6 \mathrm{mg} \mathrm{dm}{ }^{-3} ; \mathrm{K}=154.4 \mathrm{mg} \mathrm{dm}^{-3}$ and organic matter $(\mathrm{OM})=0.8 \mathrm{dag} \mathrm{kg}^{-1}$. The organic compost had the following characteristics: $20.3 \mathrm{~g}$ $\mathrm{kg}^{-1}$ of total nitrogen, $3.40 \mathrm{~g} \mathrm{~kg}^{-1}$ of $\mathrm{P}, 6.3 \mathrm{~g} \mathrm{~kg}^{-1}$ of $\mathrm{K}, 12.3 .0 \mathrm{~g} \mathrm{~kg}^{-1}$ of Ca, $4.40 \mathrm{~g} \mathrm{~kg}^{-1}$ of $\mathrm{Mg}, 2.60 \mathrm{~g} \mathrm{~kg}^{-1}$ of $\mathrm{S}, 62.06 \mathrm{mg} \mathrm{kg}^{-1}$ of B, $55.90 \mathrm{mg} \mathrm{kg}^{-1}$ of $\mathrm{Zn}, 307.4$ $\mathrm{mg} \mathrm{kg}^{-1}$ of Mn, 1,770.00 mg kg-1 of Fe, according to the methodology of Raij et al. (2001).

The substrate was homogenized and placed in the planting containers. During the experimental period, irrigation was conducted via micro-sprinkler twice a day (water blade $4 \mathrm{~mm} / \mathrm{each}$ ), keeping the substrate near to water holding capacity.

Evaluations were carried out every seven days, 45 days after planting, measuring sprout emergence used to calculate the sprouting rate index (SRI), vigorous sprouting rate (VSR), average sprouting time (AST), and mortality rate (MR).

Based on these vegetative stages, the following variables were calculated according to the methodology of Maguire (1962).

- Average sprouting time (AST): average number of days from planting until detection of "Green Tip" (GT) vegetative stage (appearance of modifications in bud coloration, with the greenish tip).

- $\quad$ Sprouting rate index (SRI): number of sprouting buds produced over time, given by the equation:

$$
S R=S\left(\frac{n i}{t i}\right)(\text { buds per day })
$$

In which:

$\mathrm{ni}=$ number of buds reaching GT stage at time "i";

$$
\mathrm{ti}=\text { time in days after planting }(\mathrm{i}=1 \text { to } 45) \text {. }
$$

- Final sprouting rate (FSR): percentage of rhizophores sections with buds that reached the GT stage;

- Vigorous Sprouting Rate (VSR): percentage of rhizophores sections with buds in the GT stage that progressed to the "Open Bud" (OP) stage (open leaf appearance. VSR was calculated using the following equation:

$V S R=(\%$ of rhizophores with GT stages $) \times 100 / T F$

- $\quad$ Mortality rate (MR): percentage of rhizophores sections that remained viable and vigorous until the end of the evaluations.

The length and number of the leaves were also evaluated. The seedling length was measured by the distance from the top of the planting container, just above the surface of the substrate, to the apex of the upper leaf blade, using a ruler (millimeters). Results were expressed in $\mathrm{cm} \mathrm{plant}^{-1}$.

Data were initially tested for residual normality assumptions (Shapiro-Wilk test) and homogeneity among variances (Bartlett's test). Following, a correlation study was performed between the dependent and independent variables, calculated for the original data and standardized 
residue. Subsequently, they were submitted to regression analysis, in the $2^{\text {nd }}$-degree polynomial model. The 2nd-degree polynomial model was chosen since it represented a higher coefficient of determination $\left(\mathrm{R}^{2}\right)$ and significance of all regression coefficients. In all tests ( $t$ and $F$ ), $p<0.05$ was used as the main significance value.

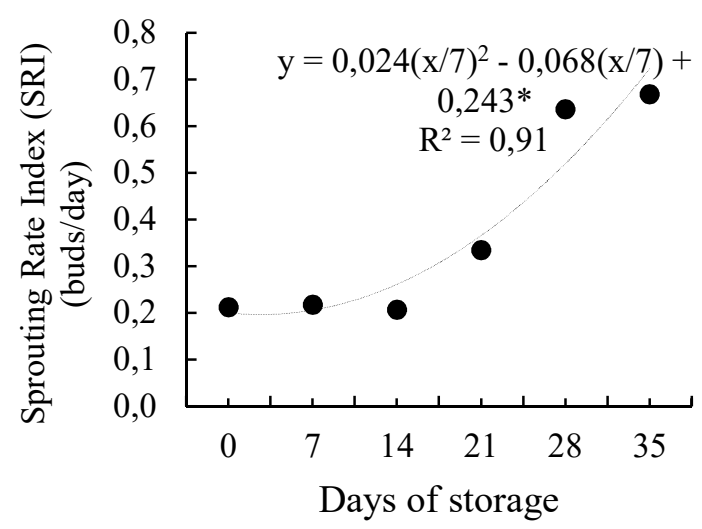

\section{RESULTS AND DISCUSSION}

The results indicate that refrigerated storage, for 21 to 35 days, promoted an increase in speed and vigorous sprouting rate of yacon rhizophores (Figure 1A and 1B), due to the lower temperature. This was the optimal condition for the evolution of buds to fully expanded leaf pairs.
(A)

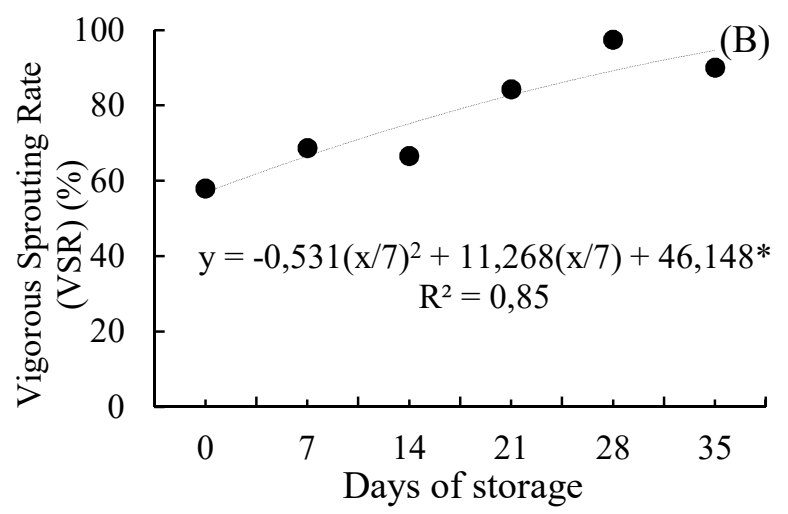

Figure 1. Sprouting Rate Index (SRI) and Vigorous Sprouting Rate (VSR) in yacon seedlings from rhizophores stored under increasing cooling time in a cold chamber $\left(8\right.$ to $\left.10^{\circ} \mathrm{C}\right)$.

Alegre/ES, UFES, 2016. **, * significant in $5 \%$ and $1 \%$ of probability, by the $\mathrm{F}$ test, respectively.

The bud sprouting rate increased after 21 days of storage, especially when rhizophores were stored for 28 and 35 days (Figure 1A). These results confirm variations in the sprouting of yacon rhizophores after refrigerated storage are directly related to the influences that temperature can have on the physiology of these materials. Temperature is one of the main environmental factors that control the physiological aging and the response of plant tissues (TAIZ; ZEIGER 2013; SOUZA; FINGER 2014).
The opposite response was observed with the average sprouting time, which decreased when the rhizophores were stored between 21 and 35 days (on average three times less) (Figure 2A). Besides, the mortality rate also decreased when the rhizophores were stored in the same period, and this decrease was $50 \%$ when compared with rhizophores that were not stored under refrigeration (Figure 2 B).
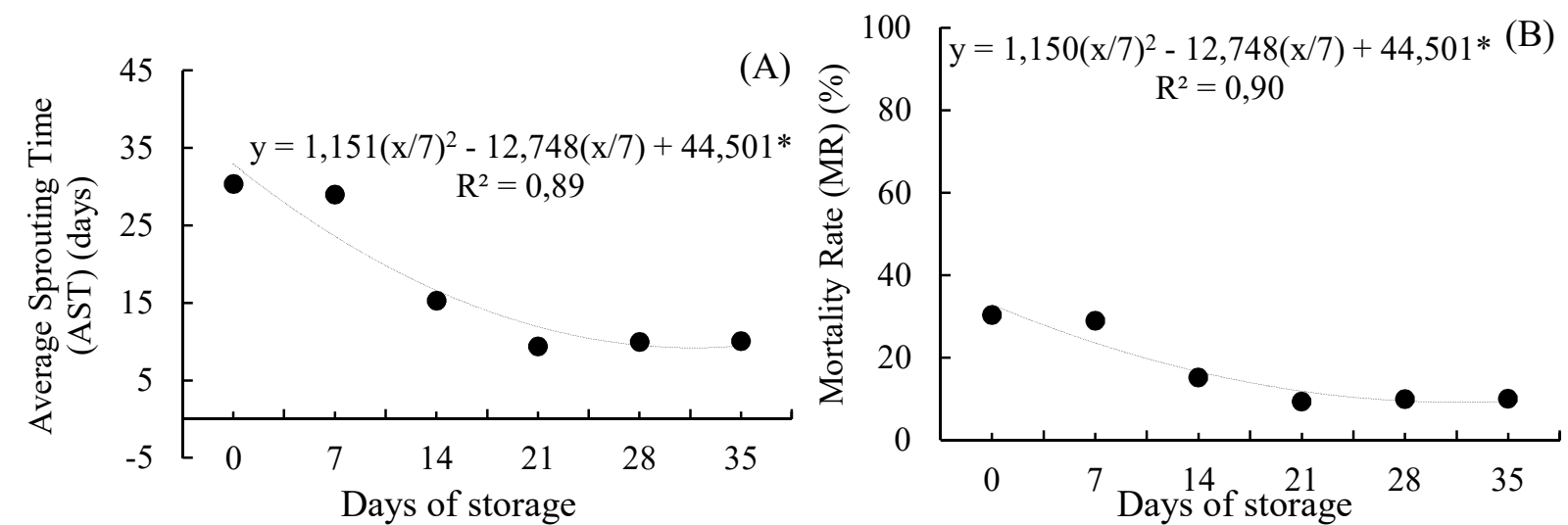

Figure 2. Average Sprouting Time (AST) and Mortality Rate (MR) in yacon seedlings from rhizophores stored under increasing cooling time in a cold chamber $\left(8\right.$ to $\left.10^{\circ} \mathrm{C}\right)$.

Alegre/ES, UFES, 2016. ** * significant in $5 \%$ and $1 \%$ of probability, by the $\mathrm{F}$ test, respectively.

Concerning the length of the seedlings and the number of leaves, a linear increase was observed in seedling length when the rhizophores were stored for a longer period (Figure 3A). A similar, but more 
pronounced result, occurred with the seedling number of leaves. Increases in refrigeration time promoted a greater number of leaves in the seedlings, in comparison to rhizophores that were not placed in refrigerated storage (Figure 3B).
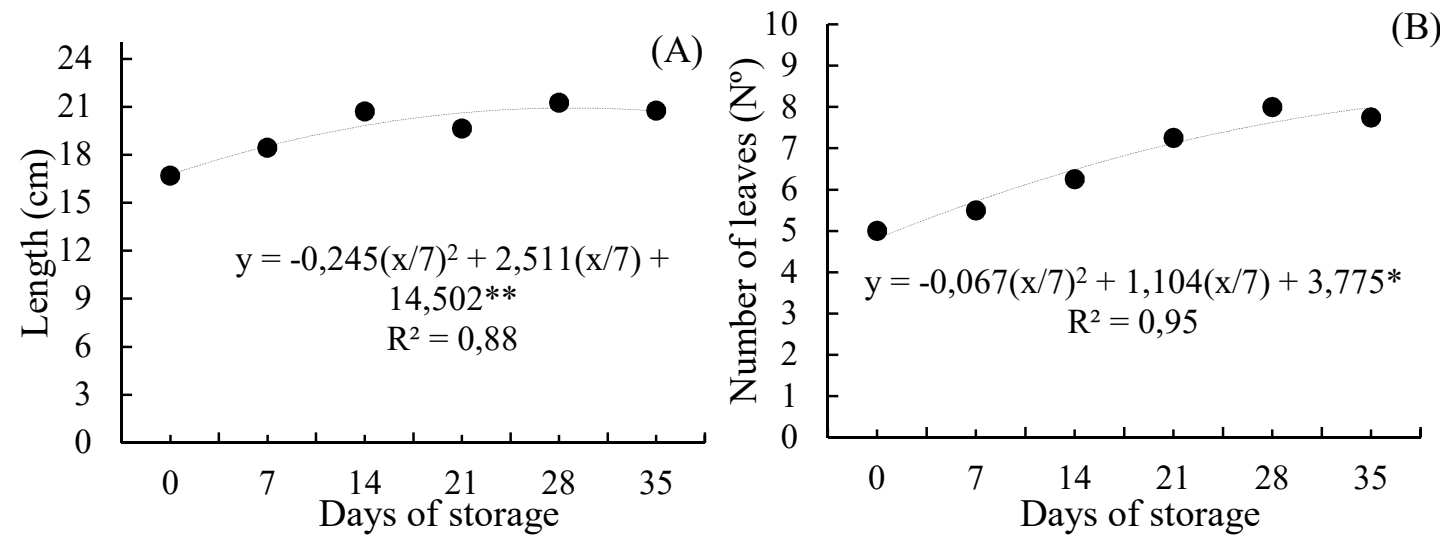

Figure 3. Length and Number of leaves of yacon seedlings from rhizophores stored under increasing cooling time in a cold chamber $\left(8\right.$ to $\left.10^{\circ} \mathrm{C}\right)$.

Alegre/ES, UFES, 2016. ${ }^{* *},{ }^{*}$ significant in $5 \%$ and $1 \%$ of probability, by the $\mathrm{F}$ test, respectively.

These results demonstrate the likely influence that temperature may have on the physiology of yacon growth, including stimulating more vigorous rhizophores buds, according to the length of refrigerated storage periods. Temperature is one of the main environmental factors controlling plant's responses, promoting or delaying modifications in their metabolism, through the activity of enzymes and hormones, being able to influence the cellular structure, flow, and absorption of nutrients, or the relation of these and other factors (TAIZ; ZEIGER 2013; SOUZA; FINGER 2014).

Many native plants to temperate regions such as Arracacia xanthorrhiza (Arracacha), Pachyrhizus Ahipa (Jacatupé), and yacon, have storage structures, some are propagative (in the case of yacon rhizophores), which benefit from low temperatures during the winter (MUSSURY et al. 2013; BIESDORF et al. 2017).

In other crops, propagule management in refrigerated storage is already used. In garlic, propagules (bulbils seeds) are kept under refrigeration, with temperatures and periods that vary according to the demands of each cultivar. This technique, known as seed vernalization, had good results in the garlic cultivation, noble cultivars, in the Cerrado region of Brazil. In the case of garlic, the process of vernalization stimulates the accumulation of cytokinin and gibberellin. When garlic bulbils are placed in optimal development conditions, early sprouting occurs, and consequently greater plant development and production (FERREIRA et al. 1981; BRAZ et al. 1997).
It is noteworthy that yacon rhizophores commonly have irregular sprouting buds, which can vary from 10 to 30 days to emerge when under normal growing conditions, especially in tropical regions (SILVA et al. 2018). Increases in propagule mortality rates result in problems to growers, as it leads to irregular plant stands and, consequently, irregular harvesting periods.

Therefore, the results obtained with a lower average sprouting time, a more vigorous sprouting rate, and lower mortality, suggest that refrigerating propagules (rhizophores) may be an alternative to growers. Cold storage of rhizophores would result in greater uniformity in sprouting and crop establishment, even leading to a more uniform harvest.

\section{CONCLUSIONS}

The results show that placing rhizophores in cold storage under temperatures of $8{ }^{\circ} \mathrm{C}\left( \pm 2{ }^{\circ} \mathrm{C}\right)$ for a period between 21 to 35 days improves sprouting rates (speed and vigorousness), reducing mortality rates and favoring initial yacon growth.

\section{ACKNOWLEDGEMENTS}

The authors are grateful to FAPES (Research Support Foundation of Espírito Santo) and $\mathrm{CNPq}$ (National Council for Scientific and Technological Development) for their financial support and for granting scholarships and research. 
RESUMO: A yacon, conhecida por suas raízes tuberosas, que são consumidas como alimento funcional, é propagada em sua maioria na forma vegetativa, via propágulos, assim chamados de rizóforos. No entanto, são órgãos de pouca durabilidade na sua forma propagativa. Logo, o armazenamento dos mesmos em condições de câmara fria, pode vir a ser uma alternativa viável para a produção de mudas da cultura. Assim, objetivou-se com o presente trabalho, verificar a influência do período de armazenamento refrigerado dos rizóforos de yacon no desenvolvimento inicial das plantas. $\mathrm{O}$ delineamento experimental foi inteiramente casualizado com oito repetições e seis tratamentos constituídos pelos períodos de armazenamento refrigerado em que os rizóforos foram submetidos: 7, 14, 21, 28 e 35 dias; e o tempo zero (plantio sem armazenamento). Os resultados demonstraram que o armazenamento refrigerado dos rizóforos, em temperatura de 8 a $10{ }^{\circ} \mathrm{C}$, por um período entre 21 a 35 dias, proporcionou melhores índices de brotação (velocidade e vigorosidade), diminuindo a taxa de mortalidade, o que favoreceu o crescimento inicial da yacon. $\mathrm{O}$ armazenamento refrigerado entre 21 e 35 dias apresentou ser uma alternativa que resultou em maior uniformidade na formação do estande de plantas na lavoura, inclusive repercutindo na uniformidade de colheita, além de minimizar o problema de sazonalidade da oferta de material propagativo da cultura.

PALAVRAS-CHAVE: Câmara fria. Conservação de propágulos. Crescimento. Smallanthus sonchifolius.

\section{REFERENCES}

BIESDORF, E. M.; BIESDORF, E. M.; ARAÚJO, E. M. de; COSTA, E. J. O.; OLIVEIRA, O. J de. Produção de mandioquinha salsa (Arracacia xanthorrhiza Bancroft) submetida a quatro épocas de plantio. Revista de Agricultura Neotropical, v. 4, n. 1, p. 43-48, 2017. https://doi.org/10.32404/rean.v4i1.1366

BOOCK, O. J.; NÓBREGA, S. A. Ambiente de armazenamento das batatas-semente e reflexo sobre a cultura. Bragantia, v. 22, n.49, p.623-34, 1963. http://dx.doi.org/10.1590/S0006-87051963000100057.

BRAZ, L. T.; DA SILVA, E. J.; CASTELLANE, P. D. The Effects of Pre-planting Refrigeration on Bulbs Over the Development and Yield of Garlic 'Chines', 'Contestado' and 'Quiteria'. In: I International Symposium on Edible Alliaceae, v. 433. p. 499-505, 1997. https://doi.org/10.17660/ActaHortic.1997.433.54

EMBRAPA. Empresa Brasileira de Pesquisa Agropecuária. Sistema brasileiro de classificação de solos. 4 th ed. Embrapa Solos - Centro Nacional de Pesquisa de Solos, 2014. 377 p.

FERREIRA, F. A.; CARDOSO, M. R. O.; FARIA, J. F. Efeito de baixas temperaturas no pré-plantio emalho (Allium sativum L.) cultivar Chonan. In: EPAMIG. Projeto Olericultura, n.78, p.23-27, 1981.

FONTES, P. C. R.; FINGER, F. L. Dormência dos tubérculos, crescimento da parte aérea e tuberização da batateira. Informe Agropecuário, v. 20, n. 197, p. 24-29, 1999.

GUSSO, A. P.; MATTANNA, P.; RICHARDS, N. Yacon: benefícios à saúde e aplicações tecnológicas. Ciência rural, v. 45, n. 5, 2015. https://doi.org/10.1590/0103-8478cr20140963

GRAU, A.; REA, J. Genetic Resources of yacon Smallanthus sonchifolius Poepp. \& Endl. In. Andean roots and tuber genetic resources, p.198-242,1997.

INMET. Dados históricos. Available from: <http://www.inmet.gov.br/portal/index.php?r=bdmep/bdmep. Accessed in March 202018.

KIMOTO, T.; CARDOSO, A. I. I.; CHENG, A. P.; KAMITSUSUJI, M. K.; LIMA, M. C. C; TSUTSUMI, C. Y.; GOTO, R. Desvernalização em alho semente devido ao atraso no plantio após a retirada da câmara frigorífica. Horticultura Brasileira, v. 14, n. 1, p. 53-55, 1996. 
MAGUIRE, J. D. Speed of germination - aid in selection and evaluation for seedling emergence and vigor. Crop Science, v. 2, p. 176-177, 1962. https://doi.org/10.2135/cropsci1962.0011183X000200020033x.

MUSSURY, R. M.; SCALON, S. P. Q.; SILVA, M. A.; SILVA, T. F.; GOMES, H; GASSI, R. Postharvest conservation of the tuberous roots of Pachyrhizus Ahipa (Wedd) Parodi. Anais da Academia Brasileira de Ciências, v. 85, n. 2, p. 761-768, 2013. https://doi.org/10.1590/S0001-37652013005000035

RAIJ, B.V.; ANDRADE, J. C.; CANTARELLA, H.; QUAGGIO, J. A. Análises químicas para avaliação da fertilidade de solos tropicais. Ed. Instituto Agronômico, 2001, 285p.

SANTANA, I.; CARDOSO, M. H.; Raiz tuberosa de yacon (Smallanthus sonchifolius): potencialidade de cultivo, aspectos tecnológicos e nutricionais. Ciência Rural, v. 38, n. 3, p. 898-906, 2008.https://doi.org/10.1590/S0103-84782008000300050.

SILVA, D. M. N.; OLIVEIRA, F. L.; CAVATTE, P. C.; QUARESMA, M. A. L. Growth and development of yacon in different periods of planting and growing conditions. Acta Scientiarum. Agronomy (Impresso) v. 40, p. 1-9, 2018. https://doi.org/10.4025/actasciagron.v40i1.39442

SOUZA, C. S.; FINGER, F. L. Reguladores vegetais sobre a brotação e crescimento de taioba refrigerada [Xanthosoma sagittifolium (L.). Revista Raízes e Amidos Tropicais, v. 10, n. 1, p. 90-99, 2014. https://doi.org/10.17766/1808-981X.2014v10n1p90-99.

TAIZ, L.; ZEIGER, E. Fisiologia Vegetal. 5th ed. Artemed. 2013.954p.

VITALI, M. S; SANCHO, G.; KATINAS, L. A revision of Smallanthus (Asteraceae, Millerieae), the "yacón" genus. Phytotaxa, v. 214, n. 1, p. 1-84, 2015. https://doi.org/10.11646/phytotaxa.214.1.1.

ZARATE, N. A. H.; HEID, D. M.; VIEIRA, M. C.; GRACIANO, J. D.; TORALES, E. P.; MECHI, I. A. Efeito do armazenamento das mudas antes do plantio na produção de mandioquinha-salsa, com e sem amontoa. In: Congresso Brasileiro de Olericultura, 51 Anais... Viçosa: ABH, 29:1672-1678, 2011. 